\title{
Physiological Characters and Alimentary Needs of Both Divergent Lines of the Barbary Partridge (Alectoris barbara, Bonnaterre, 1792) in Algeria
}

Farid Mezerdi, Kamilia Farhi

10.18805/ag.D-367

\begin{abstract}
Background: The Barbary partridge (Alectoris barbara) is a wild endemic species of North-Africa. The lack of information about this species, allows putting research focus in the hunting center of Zeralda, on the selection of a line for an improvement on the zootechnical characteristics of this population.

Methods: Over 13 weeks of follow-up, we have performed weekly measurements on 3 successive generations F12-F14 with daily measurements of food intake. We are interested at the fundamental level of the biological characterization of both divergent lines. The analysis of the effects of selection pressures on the growth to estimate the metabolizable energy of each line.

Result: During 273 days of study period, we noticed that the metabolizable energy has an average divergence between the fast line and the slow one with $0.328 \mathrm{Kcal} /$ day since birth and an average divergence of $8.899 \mathrm{Kcal} / \mathrm{day}$ towards the $13^{\text {th }}$ week in favour of the fast line. Significance noticed between males and females with a favour of the males which are more important. In addition to that, the values of weight-based consumption index imply higher indices for the slow line compared to the values of the fast line. Our results highlight the efficiency of the selection scheme. This progress will allow developing the restoration methods and/or the natural restocking populations on scientific bases.
\end{abstract}

Key words: Barbary partridge, Hunting, Line, Metabolizable energy, Physiological, Population.

\section{INTRODUCTION}

The Barbary partridge (Alectoris barbara, Bonnaterre, 1792) is one of the western palearctic birds, of the phasianidae family, order of galliformes (Geroudet, 1978 ; Cramps and Simmons, 1980; Heinzel et al., 1995). Its range presents a quite extensive distribution in north Africa, delimited by the Mediterranean from the north and the desert from south, including the canary islands and Sardinia (Heim de Balsacand Mayaud, 1962; Etchcopar and Hue, 1964; Geroudet, 1978; Ledant et al., 1981; Alaoui, 2001). It frequents the clear open locations and the steppes of the Saharan Atlas (Maghnouj, 1983; Farhi and Belhamra, 2012; Idouhar, 2012; Aourir et al., 2014; Mezerdi et al., 2017, Mezerdi et al., 2021). The physiological characters of the birth, Fotsa et al., (2001) found that there is no significant effect between both divergent lines of the local hen. The objective of the research is to study the selection effects of both divergent lines on the energetic of the Barbary partridge. That's why our study is based on the weekly measurements during the breeding phase of 13 weeks and for the 3 successive generations F12-F14. Also, we are interested on the fundamental level of the physiological characterization of both divergent lines. The analysis of the pressures selection effects on the energetic and alimentary needs. In the same way, we will present successively the direct and indirect effects.

\section{MATERIALS AND METHODS}

The birds origin is from a wild population of Beni-Slimane region (36 14'03.38LN and $\left.319^{\prime} 26.20 \mathrm{LE}\right)$ in the province of
Laboratory Promotion of Innovation in Agriculture in Arid Regions, Department of Agronomic Science, University of Biskra, Algeria.

Corresponding Author: Farid Mezerdi, Laboratory Promotion of Innovation in Agriculture in Arid Regions, Department of Agronomic Science, University of Biskra, Algeria. Email: mezerdif@yahoo.fr

How to cite this article: Mezerdi, F. and Farhi, K. (2022). Physiological Characters and Alimentary Needs of Both Divergent Lines of the Barbary Partridge (Alectoris barbara, Bonnaterre, 1792) in Algeria. Agricultural Science Digest. DOI: 10.18805/ag.D-367.

Submitted: 07-06-2021 Accepted: 04-12-2021 Online: 06-01-2022

Medea. Our research was studied in Zeralda Cynegetique Center where domiciled its first research program. The flight feathers of the partridge chicks of a first day of the fast line are more developed and longer than the feathers of the coverts of the wings, on the other wings as regards the slow line the flight feathers of the chicks were shorter and sometimes they did not appear in front of the wing cover feathers (Fig 1) (Mezerdi, 2011,Mezerdi et al., 2015 ;Mezerdi, 2015). After this selection of the chicks [fast line (fL) and slow line (sL)], we took $\mathrm{N}=80$ chicks $(\mathrm{N} 1=40$ fast te $\mathrm{N} 2=$ 40 slow) from the second series in 2012, $N=100$ chicks ( $\mathrm{N} 1=50$ fast te $\mathrm{N} 2=50$ slow) from the second series in 2013 and the same number of chicks from the fourth series in 2014. To monitor energy and foodneeds, wereared the lines separately. We performed 2,982weight measurements on the birds of bothlines ( $N=213)$, over three successive 
generations F12-F13 and F14, during three years 2012-2013 and 2014

\section{Analysis of the results}

After the weekly weight measurements, the calculation of metabolizable energy was based on the equation from Nott and Taylor (1993), whichis as follows:

\section{EM $(\mathrm{Kcl} /$ day $)=97.88 \times(\text { weight }(\mathrm{kg}))^{0.723}$}

The statistical processing of metabolizable energy takes into account the genetic effects (lineage). This was followed by comparisons of average, withusing the Fischer PLSD Posttestwith a probability $(\alpha=5 \%)$

\section{RESULTS AND DISCUSSION}

The genetic effect on the variability of metabolizable energy during the years of: 2012, 2013 and 2014

The genetic effect on the variability of metabolizable energy, are strongly significant during the whole period of 13 weeks of follow-up in 2012, 2013 and 2014 (Table 1). For example, the genetic effect the average gap between the fast line

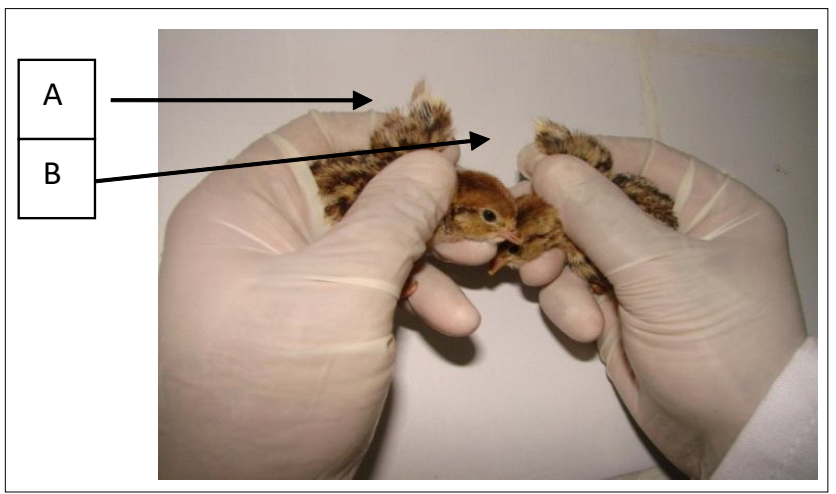

Fig 1: The feather form of the fast line $f L(A)$ and the slow line $s L(B)$. and the slow one (sL-fL $=-0.328 \mathrm{Kcal} /$ day) since the birth age (Anova test; $\mathrm{F}=362.324 ; \mathrm{P}=<0.0001$ ) and an average gap of (sL-fL $=-8.899 \mathrm{Kcal} /$ day) until the $13^{\text {th }}$ week (Anova test; $\mathrm{F}=4042.617 ; \mathrm{P}=<0.0001$ ) in favour of the fast line. It is also noted that the metabolizable energy exhibits a variation of the environment which is expressed in the various weeks of follow-up. For example, the generation effect on the variability of metabolizable energy is significant at birth between 2012-2014 with an average difference (0.071 ) (Anova test; $\mathrm{P}=0.0009$ ). During the 2 nd week, the generation effect appears between 2012-2013 with an average difference of $(-0,200)$ (Anova test; $\mathrm{P}=0.0115)$ and between 2012-2014 with an average difference of $(-0.243)$ (Anova test; $\mathrm{P}=0.0020$ ). From the 9 th week, the generation effect is significant between 2012-2013 and between 20122014 until the 13th week, with an average difference of (0.901) (Anova test; $\mathrm{P}=<0,0001$ ) between $2012-2013$ and an average deviation of $(-1,149)$ (Anova test; $\mathrm{P}=<0.0001$ ). This generation effect corresponds to the effect of the environment between years.

We take for example the year 2012, in the interval of 91 days of follow-up, the analysis of variances presents an important multiplicity 12 times $(51.297 \mathrm{Kcal} /$ day / 4.059Kcal/ day $=12,63$ ) for first day to 91 days of metabolizable energy of both lines of our chicks' sample. The average of the metabolizable energy of the fast line was evolved from $4.059 \pm 0.044 \mathrm{Kcal} / \mathrm{day}$ to $51.297 \pm 0.933 \mathrm{Kcal} / \mathrm{day}$, either a daily average evolution of $0.52 \mathrm{Kcal} /$ day [(51.297 Kcal/day$4.059 \mathrm{Kcal} / \mathrm{day}) / 91$ days $=0.52 \mathrm{Kcal} / \mathrm{day}]$ and for the slow line $3.537 \pm 0.123 \mathrm{Kcal} /$ day to $42.391 \pm 1.235 \mathrm{Kcal} /$ day, either a daily average evolution of $0.42 \mathrm{Kcal} / \mathrm{day}[(42.391 \mathrm{Kcal} /$ day $-3.537 \mathrm{Kcal} / \mathrm{day}) / 91$ days $=0.42 \mathrm{Kcal} / \mathrm{day}](\mathrm{Fig} \mathrm{2})$. The minimum value of the metabolizable energy for the fast line at birth was $3.999 \mathrm{Kcal} /$ day and it achieves a maximum value

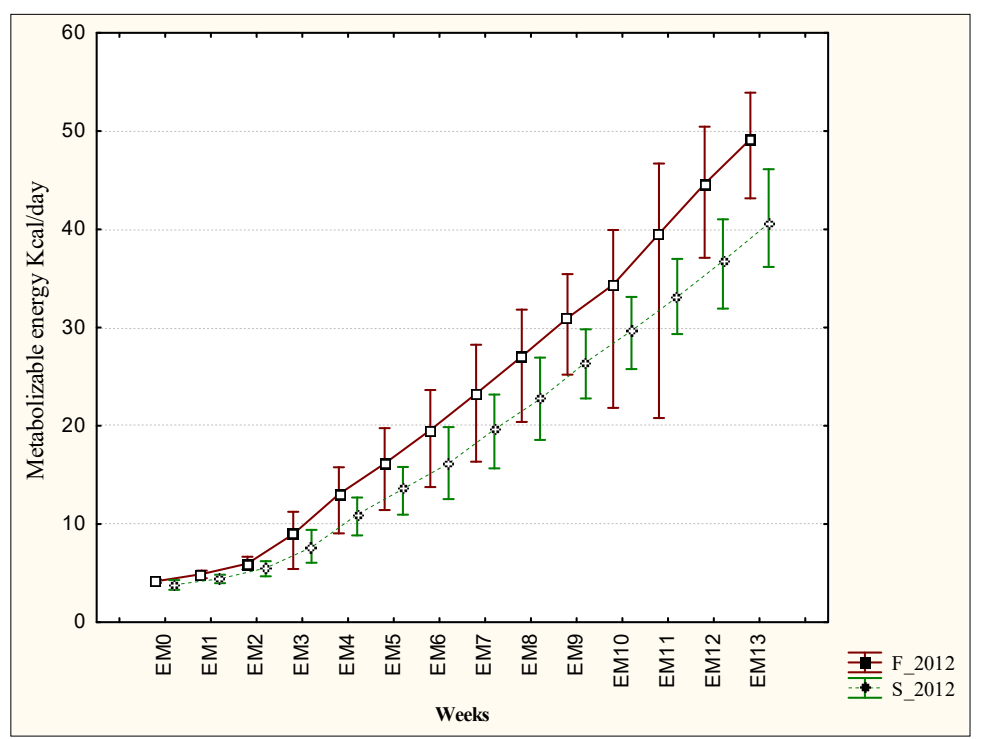

Fig 2: Characteristic variability of the metabolizable energy between the fast $(F)$ and slow $(S)$ line during the first 13 weeks of age in 2012. 
Physiological Characters and Alimentary Needs of Both Divergent Lines of the Barbary Partridge (Alectoris barbara,...

Table 1: Interline comparison for the energetic needs variability during the years of 2012, 2013 and 2014.

\begin{tabular}{|c|c|c|c|c|}
\hline \multirow{3}{*}{ The effects by Week $W^{2}$} & \multicolumn{3}{|c|}{ The energetic needs $\left({ }^{* 1}\right)$} & \multirow{3}{*}{$\begin{array}{c}\text { Genetic effects } \\
\left(\mathrm{EML}^{4}\right)\end{array}$} \\
\hline & \multicolumn{3}{|c|}{ Generation effects $\mathrm{EMG}^{3}$} & \\
\hline & $2012-2013$ & 2012-2014 & 2013-2014 & \\
\hline Wo & -0.033 & $-0.071^{*}$ & -0.038 & $-0.328^{*}$ \\
\hline W1 & $-0,045$ & $-0,062$ & $-0,017$ & $-0,495^{\star}$ \\
\hline W2 & $-0,200^{*}$ & $-0,243^{*}$ & $-0,042$ & $-0,499^{*}$ \\
\hline W3 & $-0,211$ & $-0,280$ & $-0,070$ & $-1,219^{*}$ \\
\hline W4 & $-0,185$ & $-0,297$ & $-0,113$ & $-2,001^{*}$ \\
\hline W5 & $-0,153$ & $-0,185$ & $-0,032$ & $-2,465^{*}$ \\
\hline W6 & $-0,336$ & $-0,399$ & $-0,062$ & $-3,468^{*}$ \\
\hline W7 & $-0,355$ & $-0,348$ & 0,007 & $-3,787^{*}$ \\
\hline W8 & $-0,404$ & $-0,414$ & $-0,010$ & $-4,625^{*}$ \\
\hline W9 & $-0,598^{*}$ & $-0,597^{*}$ & 0,0004961 & $-4,856^{*}$ \\
\hline W10 & $-0,906^{*}$ & $-0,942^{*}$ & $-0,036$ & $-5,245^{\star}$ \\
\hline W11 & $-1,190^{*}$ & $-1,186^{*}$ & 0,004 & $-7,309^{*}$ \\
\hline W12 & $-1,165^{\star}$ & $-1,261^{*}$ & $-0,096$ & $-8,240^{*}$ \\
\hline W13 & $-0,901^{*}$ & $-1,149^{*}$ & $-0,248$ & $-8,899^{*}$ \\
\hline
\end{tabular}

1*: Significant $(p<0.05) ;{ }^{2} \mathrm{~W}$ : Week; ${ }^{3} \mathrm{EMG}$ : Genaration effects (Energie metabolizable 2012, 2013 and 2014); ${ }^{4}$ EML : Genetic effects (Energie metabolizable between slow line and fast line).

of $53.915 \mathrm{Kcal} / \mathrm{day}$ during the $13^{\text {th }}$ week, with a variation coefficient between 2.9 and 18.1 per cent.

The same case during 2013 and 2014, the interval of 91 days of follow-up, the variance analysis presents an evolution of the metabolizable energy of 12 times for both lines of our sample of chicks. The average of the metabolizable energy for the fast line during 2013 went from $4.073 \pm 0.095 \mathrm{Kcal} /$ day to $51.923 \pm 0.573 \mathrm{Kcal} /$ day, either a daily average evolution of $0.52 \mathrm{Kcal} / \mathrm{day}$ and the slow one of $3.606 \pm 0.227 \mathrm{Kcal} /$ day to $42.749 \pm 1.216 \mathrm{Kcal} /$ day, either a daily average evolution of $0.43 \mathrm{Kcal} /$ day. Also during 2014 , the average of the metabolizable energy for the fast line went from $4.109 \pm 0.066 \mathrm{Kca} /$ day to $51.847 \pm 0.568 \mathrm{Kca} /$ day, either an average daily evolution of $0.52 \mathrm{Kcal} / \mathrm{day}$ and for the females from $3.619 \pm 0.244 \mathrm{Kcal} /$ day to $43.375 \pm 1.169$ $\mathrm{Kcal} /$ day, an average daily evolution of $0.43 \mathrm{Kcal} /$ day.

The active line's animals we characterised by a low reactivity to a new stimulation (Faure, 1975) and they are not very emotional and not very aggressive (Faure, 1982). The first days of follow-up during 3 years, we have noticed that, all chicks are more associated with each other, which is shown with the experience of El-Abbassi et al. (2007). From the first days to 91 days of follow-up, purely significant differences are raised between the fast line of kk genotype and the slow line with the Kk and KK genotype, always in favour of the fast line. In our experience, the breeding conditions and the protein intake which wasensured by a supply ad libutum. Pardosudov, (2009) considers that the food availability has direct consequences over the weight increase. The controlled intra-specific comparisons of partridges show that the fast line has a significantly fast growth. Also for the energetic needs, we have noted that the metabolizable energy has an average difference between the fast and the slow line of $(\mathrm{sL}-\mathrm{fL}=-0.328 \mathrm{Kca} /$ day) since the birth age (Anova test; $\mathrm{F}=362.324 ; \mathrm{P}=<0.0001$ ) and a medium difference of ( $\mathrm{SL}-\mathrm{fL}=-8.899 \mathrm{Kca} /$ day $)$ towards the $13^{\text {th }}$ week (Anova test; $\mathrm{F}=4042.617 ; \mathrm{P}=<0.0001$ ) in favour of the fast line. Following our experience, during 273 days of follow-up, we had clearly confirmed that the intra-lines comparisons of the genetic effect constantly emphasize that the fast ones were larger than the slow ones. A well selected crossing might ameliorate the growth speed (Coinaud, 1996). A 10 weeks' age study, on a local chicken population (Galusgallus) in Cameron by Fotsa et al., 2001. Found that there is no gene $\mathrm{K}$ significant effect on the growth. Also, the fast line's weight is less than that of the slow line (Lowe and Merkley, 1986; Fotsa et al., 2009 and Mincheva et al., 2012). On the other hand, the obtained results of our Barbary partridge during 3 years prove to be similar to those of (Mezerdi, 2011). Concerning the physiological characteristics, we demonstrated that the age of chicks and their genotype influence on the energetic needs of birds, which was confirmed by Hassan and Delpech (1986) on chickens and Monika et al., (2020) on Japanese quail. In addition, the food consumption depends on the optimal energetic level of aliment of partridges after 8 weeks of breeding (Özek, 2004) and depends on the environment in nature (Didillon, 1988) and broiler diets significantly improved their performance (Rokade et al. 2018). The ecosystem is being rapidly destroyed due to habitat loss, in addition to many other factors, all of which directly and indirectly affect wildlife (Lokman Aslan et al. 2018) for that we must know and studied the physiological and behaviorism of our animals.

\section{CONCLUSION}

During our experience, we highlighted, for the energetic needs, significant medium differences, in favour of the fast 
Physiological Characters and Alimentary Needs of Both Divergent Lines of the Barbary Partridge (Alectoris barbara,...

line. The environmental factor played an important role on the studied characteristic. It was expressed in the different weeks of follow-up. So the results highlighted the value of the selection's representation, the physiological and behaviour requirements of this group of birds had been optimized. This amelioration on the scientific basis of our bird, allowed us to use well studied methods to restore and preserve this bird.

\section{REFERENCES}

Alaoui, M.Y. (2001). Mise en évidence d'une race de montagne de Perdrix Gambra (Alectoris barbara) dans le haut-atlas marocain. Game and Wildlife Science. 18(3). 451-457.

Aourir, M., El Abbassi, A. and Znari, M. (2014). Growth patterns in Barbary partridges Alectoris Barbara originated from lowand high elevations in West central Morocco. Avocetta. 38: $45-51$.

Coinaud, J.E. (1996). Le picage chez le faisan commun. Thèse Doctorat Vétérinaire, école nationale vétérinaire d'Alfort. pp. 208.

Cramp, S., Simmons K.E.L. (1980). Handbook of the birds of Europe, the Middle East and North Africa.Oxford University Press 2: $32-49$.

Didillon, M.C. (1988). Régime alimentaire de la Perdrix Rochassière (Alectoris graeca saxatilis $X$ Alectoris rufa rufa) dans les Alpes Maritimes. Gibier Faune Sauvage. 5: 149-170.

El Abbassi, A., Znari, M., BA M'hamed, S. and Aourir, M. (2007). Ontogénie du comportement chez la Perdrix gambra Alectoris barbara (Aves: Galliformes). Biomatec Echo. 2(5): 76-84.

Etchecopar, R.D. andHüe,F.(1964). Les oiseaux du Nord de la mer Rougeaux Canaries. Ed; Boudée et Cie. Paris. pp .606.

Farhi, Y. and Belhamra, M.(2012). Avifaune des Ziban. Ed Guerfa, 164 pages.

Faure, J.M. (1975). Etude des liaisons entre comportement en open-field et émotivité chez le jeune poussin. INRA, Ann. Génét. Sel. Anim. 7(2): 197-204.

Faure, J.M. (1982). Analyse génétique du comportement en openfield du jeune poussin (Gallus gallusdomesticus). Ann. Génét. Sel. Anim 14(2): 187-212.

Fotsa, J.C., Merat, P. and Bordas, A. (2001). Effect of the slow (K) or rapid $(k+)$ feathering gene on body and feather growth and fatness according to ambient temperature in a Leghorn $\times$ Brown egg type cross. Genetics Selection and Evolution. 33: 659-670.

Fotsa, J.C., Pone, D.K., Manjeli, Y., ObounouZibi, L. and Zoyuim, A.M. (2009). Effets du gène d'emplumement lent $\left(K^{*} K\right)$ ou rapide $\left(K^{*} N\right)$ et des rations protéiniques sur les performances des poulets de chair en zone forestière humide du Cameroun. Livestock Research for Rural Development. 21(1).

Geroudet, P. (1978). Grands échassiers, Gallinacés, Rales d'Europe. Ed; Delachaux etNiestlé, Lausane, pp. 429.

Hassan, A.S. and Delpech, P.(1986). Energie métabolisable et digestibilité azotée chez les poulets en croissance: Influence du génotype, de l'âge et du régime. Génét. Sél. Evol. 18(2). 225-236.
Heim DeBalsac, H. and Mayaud, N. (1962). Oiseaux du Nord, Ouest de l'Afrique. Encyclopédie ornithologique. Ed; Lenchevalier. Paris. pp. 487.

Heinzel, H., Filter, R. and Parslow, J.(1995). Guide Heinzel les oiseaux d'Europe. D'Afrique de Nord et de Moyen-Orient, pp. 388.

Idouhar-Saadi, H. (2012). Analyse des facteurs de mortalités de la Perdrix gambra (Alectoris barbara) et la Perdrix choukar (Alectoris chukar) (Centre cynégétique et la réserve de chasse de Zéralda. Thèse Doctorat. Ecole Nationale Supérieure Agronomique, El-Harrach, Alger, pp. 155.

Ledant, J.P., Jacob, J.P., Jacobs, P., Malher, F., Ochando, B. and Roche, J. (1981). Mise à jour de l'avifaune Algérienne. Le Gerfaut. Rev. Belg. d'ornithologie. 295-398.

Logman Aslan, Özdemir Adizel and Tunahan Sancak (2018). Treatment and rehabilitation of Wild Birds and Mammals. Indian Journal of Animal Research. 52: 623-627.

Lowe, P. and Merkley, J.W. (1986). Association of genotypes for rate of feathering in broilers with production and carcass composition traits. Effect of genotypes, sex and diet on growth and feed conversion. Poultry Science. 65: 18531858.

Maghnouj, M.(1983). Contribution à l'étude de l'écologie de la Perdrix gambra (Alectoris barbara) au Maroc. Mémoire de fin d'étude, Ins. Agr. et Vétérinaire Hassan II, Rabat. pp. 110.

Mezerdi, F. (2011). Connaissance, conservation et gestion de la population de la perdrix gambra (Alectoris barbara, Bonnaterre 1792) en Algérie. Mémoire Magister. Univ de Biskra. pp. 83.

Mezerdi, F., Huguenin, J. and Belhamra, M. (2015). Variabilité des caractères tarse, aile pliée et l'évolution pondérale chez deux lignées divergentes de la perdrix gambra (Alectoris barbara, Bonnaterre, 1792). Courier de savoir 19: 101-108.

Mezerdi, F. (2015). Biologie de la reproduction d'une population captive de la Perdrix gambra (Alectoris barbara) et dynamique des populations en milieux prés forestiers et présahariens en Algérie. Thèse de doctorat. Université de Biskra. pp.136.

Mezerdi, F., Khataoui, S., Boukrabouza, A., Larinouna, F. and Belhamra, M. (2017). Données sur les caractères biométriques des œufs de la Perdrix gambra, Alectoris barbara. Bonnaterre, 1792 (Aves: Phasianidae), issues de la nature vs élevage en captivité. Courier de savoir. 22: 41-44.

Mezerdi, F., Farhi, K. and Belhamra, M. (2021). Comparison of the reproduction success of the Barbary partridge, Alectoris barbara (Bonnaterre, 1792) (Aves Phasianidae) of the two protected areas in Algeria. Biodiversity Journal. 12(1). 195-200.

Mincheva, N., Lalev, M., Oblakova, M., Hristakieva, P. and Ivanova, I. (2012). Effect of featheringalleles $(K / k+)$ on laying performance, hatchability parameters and some body measurements in two lines of white plymouth rock hens. Biotechnology in Animal Husbandry. 28(3): 405-414.

Monika, M., Rokade J.J., Narayan R., Saxena V.K., Panda, S. and Gopi, M. (2020). Studies on growth performance and genetic parameters of three varieties of domesticated Japanese Quail. Indian Journal of Animal Research. 54: 1338-1342. 
Physiological Characters and Alimentary Needs of Both Divergent Lines of the Barbary Partridge (Alectoris barbara,...

Nott, H.M.R. and Taylor, E.J. (1993). The energy requirements of pet birds. Proceedings of the association of avian veterinarians, pp. 233-239.

Özek, K. (2004). Effect of energy level in the diet on body weight, feed consumption and feed conversion ratio at early growth period in the chukar partridge (Alectoris chukar chukar) raised in closed confinement. Revue Medicine Veterinary. 155(3): 163-166.

Pardosudov, V. (2009). Development of spatial memory and the hippocampus under nutritional stress: Adaptive priorities or developmental constraint in brain development? [Dukas, R. and Ratcliffe, J.M. (Eds.). Cognitive Ecology II. University of Chicago Press, pp. 88-90.

Rokade, J.J., Kagate, M., Bhanja, S.K., Mehra, M., Goel, A., Vispute, M. and Mandal, A.B. (2018). Effect of mannanoligosaccharides (MOS) supplementation on performance, immunity and HSP70 gene expression in broiler chicken during hot-dry summer. Indian Journal of Animal Research. 52: $868-874$. 